\title{
Statistical multiplexing of identical bursty sources in an ATM network
}

\section{Dittmann, Lars; Jacobsen, Søren B}

Published in:

Global Telecommunications Conference and Exhibition

Link to article, DOI:

10.1109/GLOCOM.1988.26037

Publication date:

1988

Document Version

Publisher's PDF, also known as Version of record

Link back to DTU Orbit

Citation (APA):

Dittmann, L., \& Jacobsen, S. B. (1988). Statistical multiplexing of identical bursty sources in an ATM network. In Global Telecommunications Conference and Exhibition: Communications for the Information Age (Vol. Volume 3, pp. 1293-1297). IEEE. https://doi.org/10.1109/GLOCOM.1988.26037

\section{General rights}

Copyright and moral rights for the publications made accessible in the public portal are retained by the authors and/or other copyright owners and it is a condition of accessing publications that users recognise and abide by the legal requirements associated with these rights.

- Users may download and print one copy of any publication from the public portal for the purpose of private study or research.

- You may not further distribute the material or use it for any profit-making activity or commercial gain

- You may freely distribute the URL identifying the publication in the public portal 


\title{
STATISTICAL MULTIPLEXING OF \\ IDENTICAL BURSTY SOURCES IN AN ATM NETWORK
}

\author{
Lars Dittmann \& Søren B. Jacobsen \\ Electromagnetics Institute \\ Technical University of Denmark Building 348 \\ DK-2800 Lyngby, Denmark \\ Telephone + 45 (0) 2881444 \\ Telex 37529 DTHDIA DK (att. Electromagnetics Institute)
}

\begin{abstract}
In a broadband communication network based on the ATM concept it is suggested to use statistical multiplexing to gain better utilization of the bandwith. This paper analyses a statistical multiplexer where a number of identical bursty sources are multiplexed by use of a common buffer. Key parameters are identified and results concerning how the cell loss probability depends on these are obtained and discussed.
\end{abstract}

\section{INTRODUCTION.}

In recent years much effort has been made to develop a flexible broadband communication network capable of carrying all kinds of information. One outcome has been the concept, asynchronous transfer mode (ATM) [1], [2], [3], in which it is proposed to use statistical multiplexing in order to gain better utilization of the network resources.

The use of statistical multiplexing, where information flow might occasionally exceed the capacity of the link makes it necessary to have buffers. In a switching cell the buffers might be placed at the outlets, in the crosspoints, or at the inlets. The first approach corresponds to a multiplexer where all sources share one common buffer while in the second and third approach each source is connected to a separate buffer. According to [4] it is not recommendable to place the buffers at the inlets.

A multiplexer where each source is connected to a separate buffer is quite difficult to model analytically. Only when data arrive according to a Poisson or a Compound Poisson Process, analytical result have been obtained. In [5] exact results are obtained for a token ring with exhaustive cyclic service. When nonexhaustive cyclic service is assumed results have been obtained in [6] based on a certain assumption of independence.

A multiplexer with one common buffer is much simpler to model and it is therefore possible to get results for quite complicated arrival processes for example the $\mathrm{N}$-process described in [7].

An important characteristic of an arrival process is the burstiness which can be defined in different ways. The simplest way to define burstiness is as the fraction, peak bitrate divided by long term mean bitrate. This definition is used in [8]. A more sophisticated definition is the squared coefficient of variation of the interarrival time, described in [9], and used as one of 4 parameters in [10] to approximate a complicated superposed arrival process by a Markov Modulated Poisson Process. A third way of characterizing burstiness is the peakedness characterization [11]. Results obtained in [12] indicate that this characterization yields more accurate results in most cases

[13] presents performance analysis when variable bitrate video sources are statistically multiplexed.

The aim of this paper is to investigate how the overflow probability of a statistical multiplexer with one common buffer varies as a function of: Number of sources, burstiness of the sources, peak bitrate of the sources, the size of the buffer and the load on the output.

We have chosen to use the Uniform Arrival and Service model (UAS) presented in [14] in the case with infinite buffer size and used in [15] in the case with finite buffer size. There are three reasons for this choice: First, it makes it possible to use the simple definition of burstiness. Second, it is a quite general model because it makes no detailed assumptions about how the multiplexer is designed. Third, it seems to yield accurate results in many cases, see [15] and [16].

39.6.1.

$\mathrm{CH} 2535-3 / 88 / 0000-1293 \$ 1.00 @ 1988$ IEEE 
Since we want to analyse the performance of statistical multiplexing in an ATM packet network where the data stream is divided into cells (packets) of fixed short length, the continuous UAS model is used on a discrete problem. We are mainly interested in the probability of overflow of the buffer when it is capable of containing several hundreds of cells and in this case the inaccuracies introduced by using a continuous model is negligible.

\section{THE MODEL}

We have a buffer with finite capacity receiving data from $\mathbf{N}$ identical sources. Each source alternates, independently of the others, between an on- and an off-state. The duration of the onstate (off-state) is exponentially distributed with mean $t_{\text {on }}\left(t_{o f f}\right)$. When a source is on, it transmits data to the buffer with a constant bitrate of $f_{\text {peak }}$ $\mathrm{bit} / \mathrm{s}$. In the off-state no data is transmitted. The mean bitrate of each source is:

$$
f_{\text {mean }}=f_{\text {peak }} \cdot \frac{t_{\text {on }}}{t_{\text {on }}+t_{\text {off }}}
$$

The burstiness $b$ is defined by:

$$
\mathrm{b}=\frac{\mathrm{f}_{\text {peak }}}{\mathrm{f}_{\text {mean }}}
$$

The output rate from the buffer, when not empty, is $f_{\text {out }}$ and the instantanous rate of change in the buffer, when not empty and with $r$ sources on is $r \cdot f_{\text {peak }}-f_{\text {out }}$.

The capacity of the buffer is $\mathrm{m} \cdot \mathrm{N}$ cells, i.e. $\mathrm{m}$ is the buffersize pr. source.

The load on the output line, $\rho$, is given by:

$$
\rho=N \cdot \frac{f_{\text {mean }}}{f_{\text {out }}}=N \cdot \frac{f_{\text {peak }}}{f_{\text {out }}} \cdot \frac{t_{\text {on }}}{t_{\text {on }}+t_{\text {off }}}
$$

To ensure a stable system we assume that $\rho<1$.

With these assumptions the model calculates for each $r=0,1, \ldots, N$ the equilibrium probability $F_{r}(x)$ that $r$ sources are on and that buffer content does not exceed $x$ cells.

The cell loss probability $P_{\text {loss }}$ is defined as the number of lost cells divided by the total number of cells transmitted from the $\mathrm{N}$ sources. Due to the fact that the sources are identical this is also the cell loss probability for each source. The avarage number of cells transmitted pr. sec. is $\left(f_{\text {peak }} / n_{\text {cell }}\right) \cdot N \cdot\left(t_{\text {on }} /\left(t_{\text {on }}+t_{\text {off }}\right)\right)$, $n_{\text {cell }}$ being the number of bits in a cell. Loss of cells is only possible if $r \cdot f_{\text {peak }}>f_{\text {out }}, r$ being the number of sources in the on-state. The number of lost cells pr. sec. is then given by

$$
\frac{1}{n_{\text {cell }} r=C} \sum_{r=C}^{N}\left(r \cdot f_{\text {peak }}-f_{\text {out }}\right) u_{r}
$$

where $\mathrm{C}$ is the smallest integer greater than or equal to $f_{\text {out }} / f_{\text {peak }}, u_{r}$ is the probability of $r$ sources being on, and the buffer being held at its upper limit. An expression for $u_{r}$ as a function of $F_{r}$ and the probability of $r$ sources being on is given in equation 7 in [15]. Now the cell loss probability is:

$$
P_{\text {loss }}=\frac{\sum_{r=C}^{N}\left(r \cdot f_{\text {peak }}-f_{\text {out }}\right) \cdot u_{r}}{N \cdot f_{\text {peak }} \cdot\left(\frac{t_{\text {on }}}{t_{\text {on }}+t_{\text {of }}}\right)}
$$

$P_{\text {loss }}$ depends implicitly on the load through $f_{\text {out }}$ as it can be seen from equation 3 .

The maximum delay due to a buffer of size $\mathrm{m} \cdot \mathrm{N}$ is :

$$
\begin{aligned}
t_{\text {delay }} & =\left(n_{\text {cell }} \cdot m \cdot N\right) / f_{\text {out }} \\
& =\left(n_{\text {cell }} \cdot m \cdot b \cdot \rho\right) / f_{\text {peak }}
\end{aligned}
$$

where the last equality is obtained from equation 3.

\section{RESULTS AND COMMENTS}

In this model the cell loss probability, $P_{\text {loss, }}$ is a function of: Number of sources, $t_{\text {on }}, t_{o f r}$, peak bitrate, the buffer size, and the load. The results are split into two sections. The first section illustrates how $P_{\text {loss }}$ varies as a function of its parameters. In each calculation we allow only one parameter to vary, keeping the others fixed. However, the system parameter $f_{\text {out }}$ is not constant. In the second section we keep $f_{\text {out }}$ and total buffer size constant, varying $f_{\text {peak }}$ and the number of sources such that the load is constant.

In the first section we have chosen to keep the mean duration $t_{\text {on }}$ fixed on 0.05 sec. during all calculations. The reason is that the cell loss probability only depends on the number of cells in an average burst, i.e the product of $f_{\text {peak }}$ and $t_{\text {on }}$. 
This is due to the fact that in the UAS model the unit of information is the amount generated by one source during an average burst and this unit is also used to measure buffer content. We define the parameter a as the fraction, number of cells in an average burst to buffer capacity (in cells) pr. source, i.e. $a=f_{\text {peak }} \cdot t_{\text {on }} /\left(n_{\text {cell }} \cdot m\right)$

The results in the first section are split into four parts. In each part one parameter is allowed to vary and curves for four different peak bitrates are calculated. The four bitrates $\left(f_{\text {peak }}\right)$ are: 64 $\mathrm{kbit} / \mathrm{s}, 256 \mathrm{kbit} / \mathrm{s}, 2 \mathrm{Mbit} / \mathrm{s}$, and $140 \mathrm{Mbit} / \mathrm{s}$. In all, except one part, the buffer capacity $(\mathrm{m})$ is 32 cells pr. source. An average burst launch 12.5 cells into the buffer when the peak bitrate is $64 \mathrm{kbit} / \mathrm{s}$, 50 cells when the peak bitrate is $256 \mathrm{kbit} / \mathrm{s}, 390$ when peak bitrate is $2 \mathrm{Mbit} / \mathrm{s}$, and 27350 when the peak bitrate is $140 \mathrm{Mbit} / \mathrm{s}$. Except when a parameter is used as a variable, default values are : burstiness (b) 10 , number of sources (N) 20 , and load $(\rho) 0.6$

In the second section we have chosen $\mathrm{f}_{\mathrm{out}}=150$ $\mathrm{Mbit} / \mathrm{s}$. This is the maximum channel rate, ATM header included, suggested at the CCITT meeting in Seoul, Jan. 88. The total buffer capacity is $\mathbf{5 1 2}$ cells, implying a maximum delay of $1 \mathrm{msec}$. The mean duration $t_{\text {on }}$ is $0.1 \mathrm{msec}$. $(a=0.4)$ or $1 \mathrm{msec}$. $(a=4)$ and the burstiness is 10. Four curves corresponding to a load of 0.4 and 0.6 and $a$ of 0.4 and 4 are calculated

The cell length is kept fixed on 256 bits/cell during all calculations in the two sections. This is within the range stated in [17].

In a flexible communication network carrying all kinds of services the buffer overflow probability has to be kept at the same order of magnitude as the bit-error-rate which means about $10^{9}$.

In Fig 1.1 $P_{\text {loss }}$ varies as a function of the number of sources multiplexed. The cell loss probability decreases significantly as the number of sources multiplexed is increased in the low bitrate cases.

Fig 1.2 shows $P_{\text {loss }}$ as a function of the burstiness. When burstiness is low a small increase implies an extreme increase in cell loss probability but when burstiness is high an increase in burstiness has only small inpact on cell loss probability.

$P_{\text {loss }}$ as a function of buffer size pr. source is shown in Fig. 1.3. In the $64 \mathrm{kbit} / \mathrm{s}$ and $256 \mathrm{kbit} / \mathrm{s}$ cases the cell loss probability decreases significantly when the buffer size is increased.
This effect is small in the $2 \mathrm{Mbit} / \mathrm{s}$ and $140 \mathrm{Mbit} / \mathrm{s}$ cases.

Fig. 1.4 shows $P_{\text {loss }}$ as a function of the load. As all four curves show, then a very efficient way to lower cell loss probability is to decrease the load

Fig. 2 shows $P_{\text {loss }}$ as a function of the number of sources and peak bitrate, keeping the total information flow, $f_{\text {out }}$ and buffer size fixed, and hereby keeping a (the fraction, number of cells in an average burst to buffer capacity pr. source) fixed on 0.4 and 4

As the figures indicate, the performance of the multiplexer is heavily dependent on the number of cells transmitted in an average burst. When this number largely exceeds buffer capacity pr. source, i.e. $a \gg 1$, which is the case in the $2 \mathrm{Mbit} / \mathrm{s}$ and $140 \mathrm{Mbit} / \mathrm{s}$ cases, it is impossible to get an acceptable cell loss probability $\left(10^{-9}\right)$. When $a<1$ like in the $64 \mathrm{kbit} / \mathrm{s}$ case, acceptable performance can be achieved. The $256 \mathrm{kbit} / \mathrm{s}$ case corresponds to the case where a is slightly greater than 1 . Here acceptable performance is possible when the number of multiplexed sources is high. Fig. 2 illustrates the importance of the parameter $a$.

\section{CONCLUSIONS}

In this paper we have studied the performance of a statistical multiplexer with a common buffer and bursty sources. A uniform arrival and service model has been used to calculate the loss probability as a function of several parameters. From the results obtained we conclude that the fraction, number of cells in an average burst to buffer capacity pr source, is a more important parameter than burstiness. When this fraction is much greater than one performance will be poor unless the load is very low. If the fraction is in the order of one or less acceptable performance can be achieved. Combining small load with multiplexing of many sources can be a very efficient way to lower celi loss probability.

\section{ACKNOWLEDGEMENT}

We would like to thank Dr. Ejner Nicolaisen and Dr. Klaus Moth for there valuable assistance. For financiel support we would like to thank, the Telephone Companies in Denmark and the RACE ATMOSPHERIC project. 


\section{REFERENCES}

[1] L.T.Wu, E.Arthurs, W.D.Sincoskie, "A Packet Network for BISDN Applications", International Zurich Seminar 1988.

[2]

P.Gonet, M.Serval, J.P.Coudreuse, "Asynchronous Time Division Switching: The Way to Flexible Broadband Communications Network", Proceedings International Zurich Seminar on Digital Communications, May 1986.

J.P.Coudreuse, P.Boyer, "Asynchronous timedivision techniques for real time ISDN"s", Seminaire international sur les reseaux temps reel, Bandol, April 1986.

[4]

M.J.Karol, M.G.Hluchyj, S.M.Morgan, "Input vs. output queueing on a space-division packet switch", Globecom 86, Houston, dec. 1986.

[5] M.J.Ferguson, Y.J.Aminetzah, "Exact Results for Nonsymmetric Token Ring Systems", IEEE Transactions on Communications, Vol. COM-33, no.3, March 1985, pp 223-231.

[6] P.J.Kuehn, "Multiqueue Systems with Nonexhaustive Cyclic Service", BSTJ, Vol.58, no.3, March 1979, pp 671-698.

[7]

V.Ramaswami, "The N/G/1 Queue and its Detailed Analysis", Adv. Appl. Prob.12, 1980, pp 222.261.

[8] J.J. Kulzer, W.A.Montgomery, "Statistical Switching Architectures for Future Services". ISS 84, Florence. May 1984.

[9]

K. Sriram, W. Whitt, "Characterizing Superposition Arrival Processes in Packet Multiplexers for Voice and Data". IEEE Journal on Selected Areas in Communications, Vol. SAC-4. no.6 Sep. 1986, pp 833-846.

[10] H. Heffes, D.M. Lucantoni, "A Markov Modulated Characterization of Packetized Voice and Data Traffic and Related Statistical Multiplexer Performance", IEEE Journal on Selected Areas in Communications, Vol. SAC-4, no.6, Sep. 1986, pp 857-868.

[11] A.E. Eckberg, "Generalized Peakedness of Teletraffic Processes", Proceedings, 10 th International Teletraffic Congress, Montreal, 1983.

[12] A.E. Eckberg, Approximations for bursty land smooted arrial queueing delays based on generalized peakedness", 11 th International Teletraffic Congress, Kyoto, 1985

[13] B. Maglaris, D Anastrassiou, P. Sen, G. Karlsson, J. Robbins, "Performance Analysis of Statistical Multiplexing for Packet Video Sources", Globecom 87, Tokyo, Nov. 1987.

[14] D. Anick, D. Mitra, M.M. Sondhi, "Stochastic Theory of a Data-Handling System with ifultiple Sources", BSTJ. Vol.61, no.8, Oct. 1982, pp1871. 1894.

[15] R.C.F. Tucker, "Accurate Method for Analysis of a Packet-Speech Multiplexer with Limited Delay", IEEE Transactions on Communications, Vol.36, no.4, April 1988, pp 479-483.

[16] J.N. Daigle, J. D.Langford, "Models for Analysis of Packet Voice Communications Systems", IEEE Journal of Selected Areas in Communications, Vol. SAC-4, no.6, Sep. 1986, pp 847-855.

[17] CCITT(Rapporteur A. Papanicolaou), "Stockholm Meeting Report (Draft)", Working Party XVIII/I, Rapporteurs Meeting, Question XVIII/2.11, pp 1-21, $24-26$ sep. 1986 .

\subsection{4.}




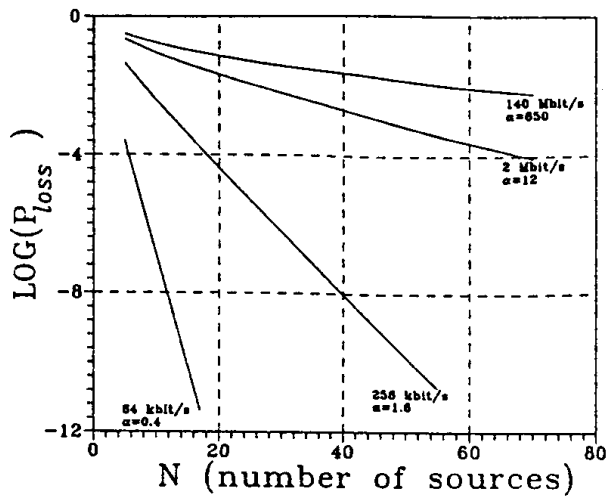

Fig 1.1

Cell-loss probability vs. number of sources with : $p=0.6, b=10$, $\mathrm{m}=32$ cells $/$ source, $\mathrm{t}_{\mathrm{on}}=0.05 \mathrm{sec}$

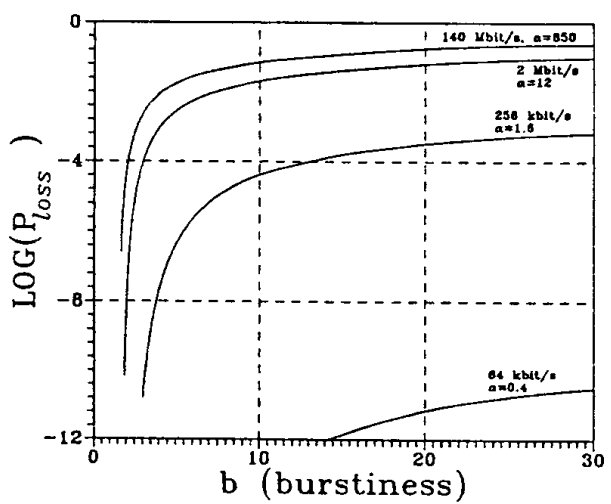

Fig 1.2

Cell-loss probalility vs. burstiness with : $\rho=0.6, N=20$,

$t_{\text {on }}=0.05$ sec. $m=32$ cells $/$ source

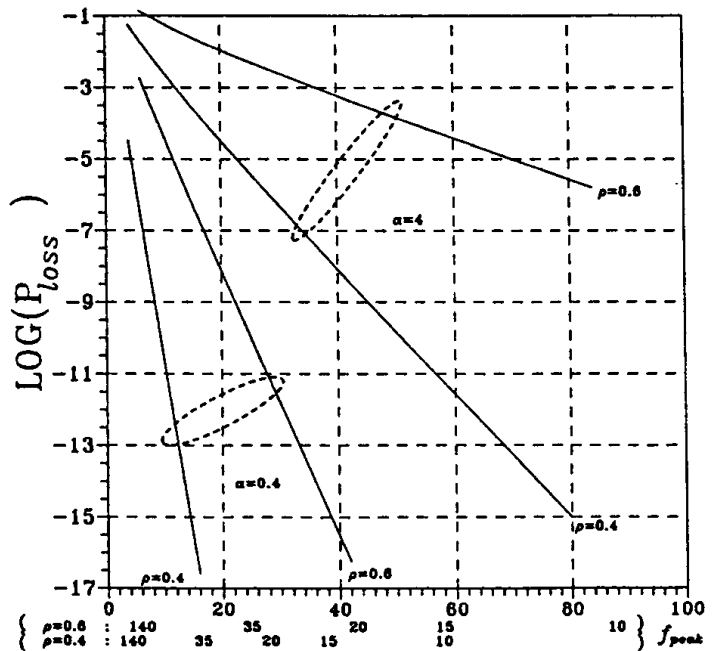

Fig 2

Cell-loss probability vs. number of sources/ $f_{\text {peak }}$ with : $b=10$,

$t_{\mathrm{n}}=0.1 \mathrm{msec}$. or $1 \mathrm{msec}$., $f_{\text {out }}=150 \mathrm{Mbit} / \mathrm{s}$,

$\mathrm{t}_{\text {delesy,max }}=1 \mathrm{msec}$., $\mathrm{m} \cdot \mathrm{N}=512$ cells.

39.6.5. 